\title{
新規水稲用水面施用剂「豆つぶ剂」の開発
}

\author{
藤田茂 樹 1 ,*, 平岡 学 ${ }^{1}$, 池内 利 祐 $^{2}$, 小林方 美 $^{3}$ \\ ${ }^{1}$ クミアイ化学工業株式会社製剂技術研究所 \\ 2クミアイ化学工業株式会社研究開発部企画課 \\ 3 クミアイ化学工業株式会社生物科学研究所
}

（2015年6月9日受理）

\section{Development of the novel formulation "MAMETSUBU" for the paddy rice}

\author{
Shigeki Fujita, ${ }^{1}$ Manabu Hiraoka, ${ }^{1}$ Toshihiro Ikeuchi ${ }^{2}$ and Masami Kobayashi ${ }^{3}$ \\ ${ }^{1}$ Kumiai Chemical Industry Co., Ltd. Formulation Technology Institute \\ ${ }^{2}$ Kumiai Chemical Industry Co., Ltd. Research \& Development Department Plannning \& Coordination Section \\ ${ }^{3}$ Kumiai Chemical Industry Co., Ltd. Life Science Research Institute, \\ 100, Shibukawa, Shimizu-ku, Shizuoka, Shizuoka 424-0053, Japan
}

Keywords: agricultural formulation, "MAMETSUBU" formulation, labor-saving, paddy field, application.

\section{は じめに}

現代の農業を取り巻く情勢として, 農業従事者の高齢化と それに伴う世代交代が挙げられる。また，農業従事者組織が 法人化するとともに, 農作地の大規模化が進みつつあり, 農 作業の全般的な効率化がますます重要になってくると考えら れる. 水田の農作業については, 農業用機械の発達により田 植えや収穫に関わる労働負荷が劇的に軽減するとともに, 農 薬防除に関しても，昨今の高性能の農薬有効成分の出現によ り，作業に要する時間は大幅に短縮された。しかし，そのよ うな中でも農薬散布に関しては, 労力を軽減する効率的な農 薬施用を可能とする省力化製剂の市場ニーズがあった。例え ば，水田用の除草剂は，10 a 当たり $3 \mathrm{~kg}$ または $1 \mathrm{~kg}$ を散布す る粒剤が主流であるが, 数 $\mathrm{kg}$ の粒剤を持ったまま田植え直 後のぬかるんだ水田に入り, 水田一面に均一に薬剤を散布

\footnotetext{
* ₹ 424-0053 静岡県静岡市清水区渋川 100

E-mail: s-hujita@kumiai-chem.co.jp

(c) 日本農薬学会
}

することは, 散布に要する時間もかかるが, それ以上に肉体 的，および精神的にも大きな負担が掛かるものであった.

このようなニーズの中で, 水という拡散媒体がある水稲分 野に限られるが，水田に入らずに畦畔から散布することを コンセプトに色々な省力化製剂が開発された。1991年には, 小規模の水田であれば，水田に入ることなく畦畔から散布す ることが可能な直接散布フロアブル剂が開発され，使用面積 を増やしていった ${ }^{1)}$. しかし, フロアブル剂は, 容器を手で 振りながら液体製剤を水田に散布するため, 風上に向かって 散布した場合は薬液が衣服に付着したり, 細かな液滴が水田 外まで飛散してしまう問題があった。一方，1994年にはフ ロアブル剂と同様に畦畔から散布ができ，かつ， $10 \mathrm{a}$ 当たり 10 個程度の製剤を水田内に投げ入れることで施用が可能な ジャンボ剤が開発され，広く普及していった ${ }^{2)}$ 。この製剂は 散布者への被曝がなく, 非常に省力的な散布が可能な製剂と いえる. しかし, これらの省力化製剤は, 水を拡散媒体とし て有効成分が広がるものであるため, 藻類などの障害物があ る水田では成分の拡散が著しく阻害される場合があった ${ }^{3)}$. このような背景の中で，市場にある省力化製剤の課題や， 
その他の製剤化の視点を踏まえ，使いやすい新たな省力化製 剂の開発を進めた ${ }^{3-5)}$.

\section{1. 豆つぶ剤の設計}

農薬製剂は固体製剂と液体製剂に大別されるが，新規の水 面施用剂を設計するに当たり，散布時の飛沫が使用者にかか ること，および稲体に薬液が付着する懸念，散布後大量に発 生するポリ容器の処理の問題を考慮し，固体製剤が新規製剤 開発の出発点となった。

次に，水田内に入らず畦畔からの散布を基本とし，ある程 度不均一に散布しても水田全体に有効成分が拡散する省力 化製剂を製剂要件として考えた。そのためには，粒剤のよう に水底に沈んだ製剤から有効成分が徐々に溶出するのではな く, 水田内の水に有効成分が短時間で分散する製剂，すなわ ち，水面に浮遊して短時間で崩壊分散する拡散型の粒状製剤 が望ましいと考えた。

ところで，省力化製剤の成分の拡散は，製剤自体の拡散力 だけではなく，風や水温の変化による水の対流の影響による ところが大きいため，従来の省力化製剂は，障害物がない水 面を有した水田では優れた拡散性を示すが，水田を耕起した 際掘り起こされる稲蒸の残骸や，春先に発生する藻類や表層 剥離によって，成分の拡散が著しく阻害される場合がある (Fig. 1)。このような藻類をはじめとする障害物の有無, さ らに水田の規模や形，風の強さや向きなど，決して一様でな い水田に対しても成分の拡散性不良を起こす影響を極力少な
くするためには，使用者が思った通りに，場合によっては 色々な散布用の道具，機械を用いてばら撒くことが可能な製 剤が好ましいと考えた。また，このように製剤を広範囲にば ら撒くことは，使用する人にとっても農薬散布に対する満足 感，安心感に繫がると考えた（Fig. 2)，具体的な製剂を設計 するに当たり，製剤の大きさを多面的に検討した結果，造粒 径が $5 \mathrm{~mm}$ と, 従来の粒剤よりも大きな豆つぶ状の製剂が散 布のしやすさ，飛距離，散布機への適性においてバランスが 取れていると判断した。また，軽量化の視点から $10 \mathrm{a}$ 当たり の施用量は，当時のフロアブル剂やジャンボ剤の半量である $250 \mathrm{~g} / 10 \mathrm{a}$ とした．以上の設計のもと「豆つぶ剤」を開発し た (Figs. 3, 4, 5).

\section{2.＼cjkstart豆つぶ刘の調製}

\section{1. 豆つふ済の組成}

豆つぶ剂の組成は，農薬有効成分，界面活性剂，製剤に硬 さを付与する結合剤, 中空体, 賦型剤としての固体担体を必 須成分とする。

界面活性剂は，製剂が水面で崩壊・分散し，成分を拡展さ せる性質を付与するものであるが，用いることができる界面 活性剤は豆つぶ剤の有効成分によって異なるため, 製剤化検 討の都度，試行錯誤を繰り返して界面活性剂の種類や配合 量，組み合わせを決定する，有効な界面活性剂は，製剤が水 に浮いたときの界面，すなわち，固相（製剤）と液相（水）, 気相（空気）の境界で作用するものであり，製剤を構成する
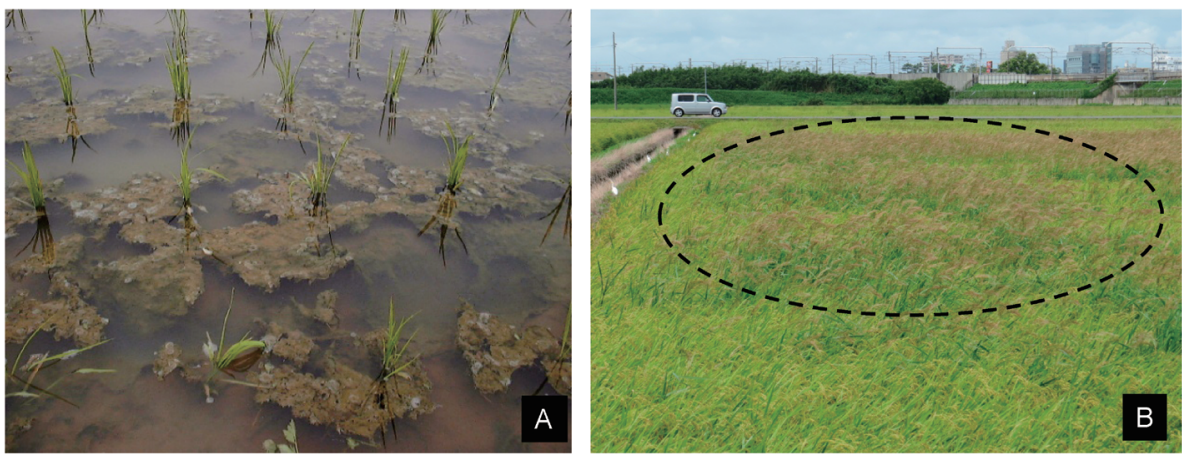

Fig. 1. Spreadable lack of active ingredient. (A) Peeling of the paddy field surface and (B) Insufficient effect of herbicide.
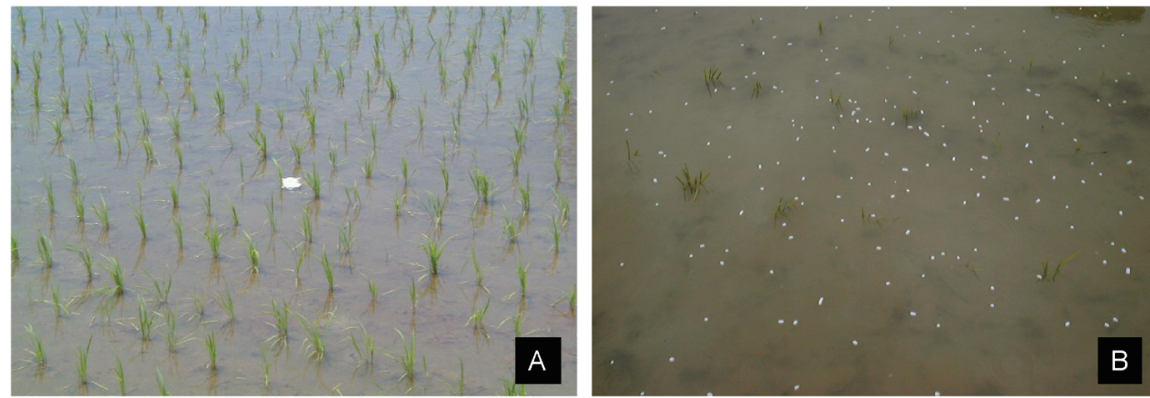

Fig. 2. State immediately after application. (A) Jumbo formulation and (B) "MAMETSUBU" formulation. 


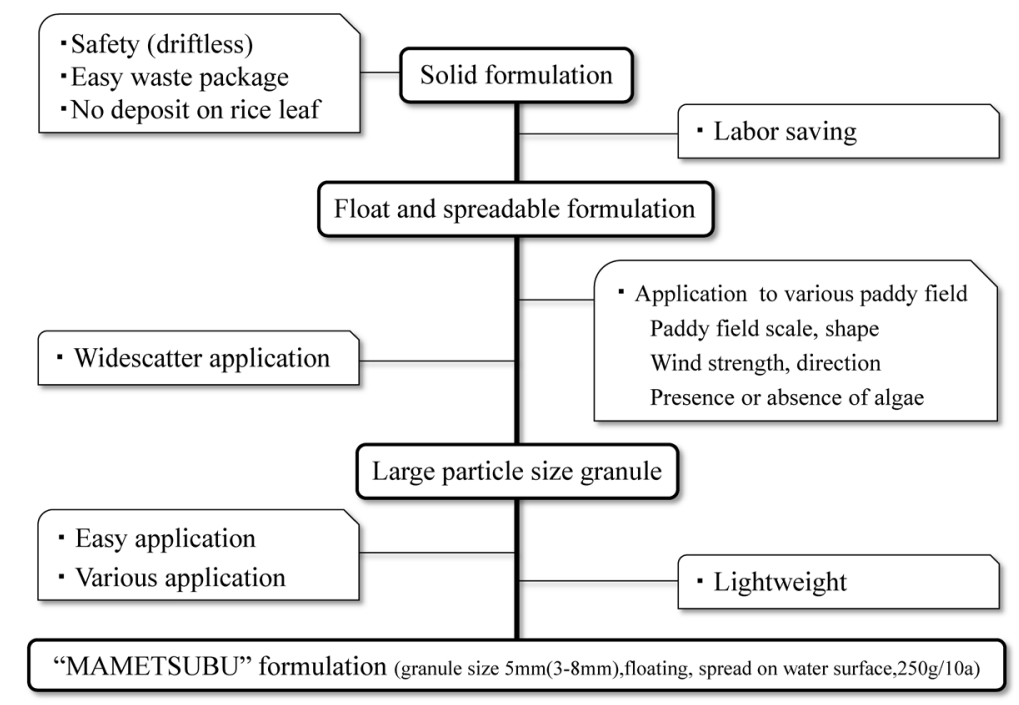

Fig. 3. Plan of the "MAMETSUBU" formulation.

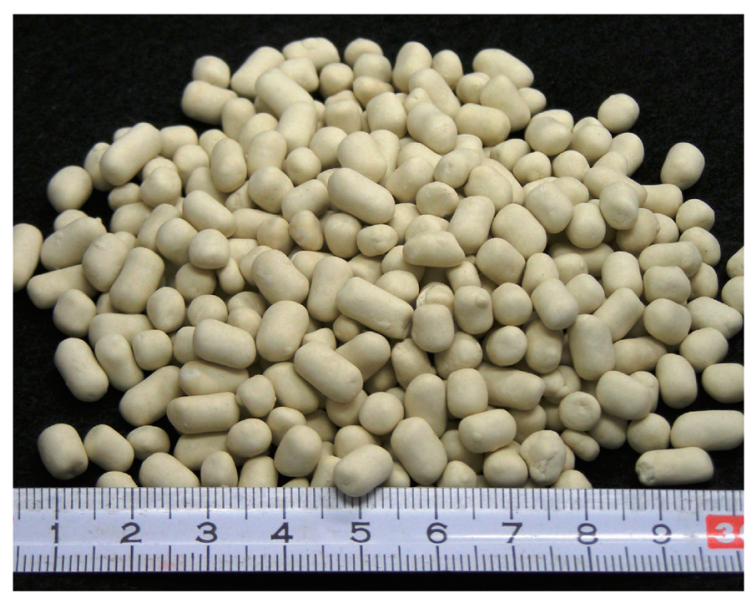

Fig. 4. "MAMETSUBU" formulation.

固体の粒子の隙間に水が浸入すると同時に粒子を分散させる 作用する界面活性剂を使用する。

中空体は製剂が水に浮く性質を付与するために配合する. 一般的な中空体としては，例えば，木粉やコルク片等の植物 由来の中空体, バーミキュライトや発泡パーライト, 発泡シ ラス，軽石等の鉱物質の中空体があるが，豆つぶ剤において は，単量体であるアクリロニトリルあるいはメタクリル酸エ ステルを共重合体させたマイクロスフェアーを用いた。ママイ クロスフェアーは粒径が数十〜数百 $\mu \mathrm{m}$ の球状の中空体であ る。この中空体はそれ自体か軽量であり高い浮力を有するこ とと，これを配合すると押し出し造粒が極めて容易となり， 押し出しの際の圧力が減少し粒が圧密な状態になりにくく なるため, 製剤組成に対し 1 数\%と少量の配合で十分な浮 力が得られると考えられる。そのため，前述の一般的な中空 体を用いる場合と異なり，製剤を構成する他の原料を余裕を 持って配合することが可能となった。
Table 1. Physical properties of the "MAMETSUBU" formulation

\begin{tabular}{lc}
\hline \multicolumn{1}{c}{ Item } & Physical property \\
\hline Bulk density & 0.4 \\
Granule size $(3-8 \mathrm{~mm})$ & $99 \%$ \\
Moisture content & $1.2 \%$ \\
Floating ratio on the water & $100 \%$ \\
Dispersion time & $6-9 \mathrm{~min}$. \\
\hline
\end{tabular}

\section{2. 豆つふ済の製造}

豆つぶ剂は前項記載の原料を必須成分として，通常の押し 出し造粒型の粒剤と同様の工程にて製造する。具体的には, 原料を均一に混合し，適量の水を加えてさらに混合した混練 物を $5 \mathrm{~mm}$ の穴が開いた金属製のプレートから押し出し造粒 し，得られた造粒物を転動させることで丸みを帯びた形状ま で整粒後, 所定の温度で乾燥し, 粒長が $3 \sim 8 \mathrm{~mm}$ 程度となる ようにふるい分けして最終製剤となる，得られた製剤の大き さにはある程度のばらつきが生じるが，散布するときにある 程度広がって飛ばすことのできる製剤となりむしろ好ましい．

\section{3. 豆つふ淯の物化性}

得られた製剤の物化性の代表值を示す（Table 1)。嵩密 度（Bulk density）は500 mL容のメスシリンダーに製剤を $500 \mathrm{~mL}$ 入れ，そのときの製剤の重量を体積で除して求め た. 粒度（Granule size）については，一定量の製剂を目開 き $8 \mathrm{~mm}$ と $3 \mathrm{~mm}$ のろるいでろるい分し， $3 \sim 8 \mathrm{~mm}$ に分布す る製剤の重量を供試した製剤の重量で除して求めた。水分 (Moisture content) はカールフィッシャー式水分測定器にて 測定した。水面浮遊率（Floating ratio on the water）は製郕 を任意に 50 粒選び取り，水を張った大型のシャーレに全粒 


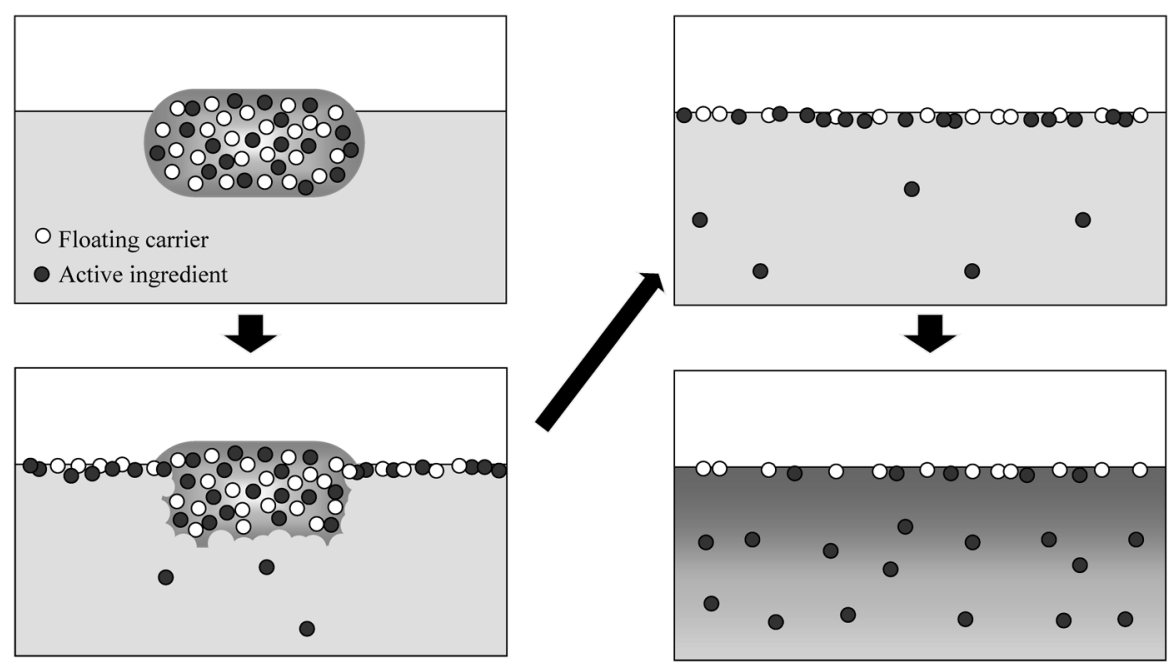

Fig. 5. Dispersion and spread of the "MAMETSUBU" formulation.

を投入し，直後に水面に浮遊する粒の数を計測した，崩壊分 散時間（Dispersion time）は, 水温 $20^{\circ} \mathrm{C}$ の水を張った大型 のシャーレに製剤 1 粒を投入し, 粒が水面で完全に崩壊分散 するまでの時間を10回繰り返し計測した。

\section{3. 豆つぶ済の散布}

豆つぶ剂を設計するに当たり, 特徴づけたのは種々の方法 で使用者が思った通りに散布することができるということで あり，製剂だけでなく散布方法についても検討を行い，豆つ ぶ剂の散布方法として有効な方法を確立した ${ }^{6,7)}$.

\section{1. 手まき散布}

道具や機械を用いずに最も単純に手作業で散布する方法で あり，10〜30a程度の水田が対象である，手袋をはめ，ひと つかみおよそ $10 \mathrm{~g}$ 程度を, 畦畔を歩きながら下手投げで豆ま きのように数 $\mathrm{m} こ ゙ と に$ 散布する. 飛距離は $3 \sim 10 \mathrm{~m}$ で $10 \mathrm{a}$ の 水田を一回りすると約 3分で散布が終了する（Fig. 6A）.

豆つぶ剂の散布は基本的には畦畔を一周しながら各辺より 行うが, 3.2. 3.4. 節の散布方法を含め, 風が強いときなど は風上から散布することも有効である.

\section{2. ひしゃく散布}

簡単な道具を用いて散布する方法であり，1 ha 程度までの 水田に有効な散布方法である．磯や堤防から魚釣りをすると きのコマセを撒くひしゃくを用いて散布する。ひとすくいで 20〜25g を下手投げで投げ入れると機械を用いることなく約

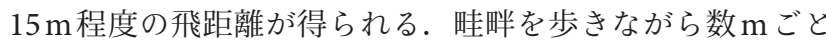
に散布する (Fig. 6B).

\section{3. 袋散布}

フロアブル剂のボトル散布をイメージした散布方法であ
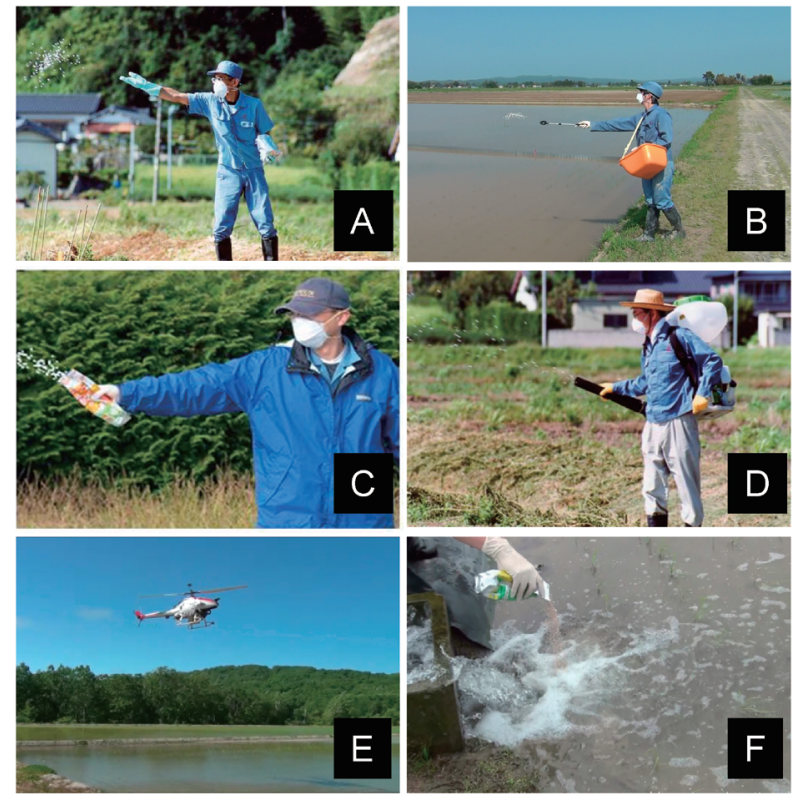

Fig. 6. Application method of the "MAMETSUBU" formulation. (A) Hand application, (B) Dipper application, (C) Package application, (D) Engine duster applicatipn, (E) Unmanned helicopter application, and (F) Application to the water inlet.

り，10〜30a程度の水田が対象である. 豆つぶ剂を包装して いるアルミ袋に特徵があり, 袋を開ける位置によって開口部 が全開とならない構造となっており，この状態で包装袋を手 で握り持ち, フロアブル剂のボトル散布の要領で, 畦畔を歩

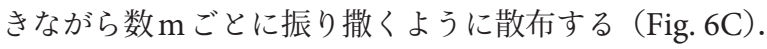

\section{4. 動力散布}

粒剤や粉剂を散布する動力散布機を用いて散布する方法で ある，粒剤や粉剂を散布する場合は, 動力散布機のシャッ ター開度を調整し一定量を連続的に散布するが, 豆つぶ剂の 
場合は，シャッターレバーの開閉を人為的に瞬時に行い，断 続的に 1 ショットずつ, 畦畔を歩きながら数 $\mathrm{m}$ ごとに散布す る. 飛距離は約 $25 \mathrm{~m}$ であり, 大型水田向きの散布方法とい える (Fig. 6D).

\section{5. 無人ヘリ散布}

粒剂の散布装置を搭載した無人へリを用い，水田上空3〜 $4 \mathrm{~m}$ を飛行しながら空中から散布する方法である。シャッ ター開度（メータリング開度）を調整し連続的に散布する か，断続的に開閉することでスポット的に散布する．散布に 要する時間は 1 ha 当たり約 3 分と短く, 大型水田向きの散布 方法といえる (Fig. 6E).

\section{6. 水口施用}

水田の水をいったん落水しておき，再び入水するときに水 口付近に豆つぶ剂を一気に投入し，水の流れを利用して水田 全体に成分を拡散させる処理方法である．本方法はフロアブ ル剂の施用方法の一つであるが豆つぶ郕にも適用することが できる（Fig. 6F）.

\section{7. ジャンボ剤}

製剂をばら撒くことが豆つぶ剂の製剤設計上の思想ではあ るが，水溶性フィルムに包装しジャンボ剤として散布するこ とも施用形態の一つである．1袋当たり $25 \mathrm{~g}$ の製剤を，通常 のジャンボ剂と同様に $10 \mathrm{a}$ 当たり 10 個を畦畔歩きながら数 $\mathrm{m}$ ごとに投げ入れて施用する．投げ入れられた製剤は，水 田の水で水溶性フィルムが溶解し, 中の豆つぶ剂が放出され て散らばりながら崩壊・分散する。

\section{4. 豆つぶ浏の拡散性}

\section{1. 初期評価}

試作した豆つぶ䩹の妥当性を評価するには, 最終的には実 際の水田を用いた評価が必要であるが，段階的に種々の評価 を行う。

まず，製剤が最低限具備する特性として，水に浮く性質， 水面で崩壊・分散する時間と挙動を把握するために, 水深 $4 \mathrm{~cm}$ とした $40 \mathrm{~cm} \times 25 \mathrm{~cm}$ のコンテナに製剤 1 粒を投入し評 価する．評価は複数の連性で行うが，期待する特性が得られ るまで製剤組成の検討を繰り返し行う。

次の段階として, 実験室規模の成分拡散性評価を行う。実 験は幅 $15 \mathrm{~cm}$, 長さ $4 \mathrm{~m}$ のプラスチック製雨卜イを用い, 水 深 $4 \mathrm{~cm}$ とした水路の片端に, 水路の面積に応じた薬量の製 剂を施用し，所定時間ごとに所定の場所から採水し，水の中 に含まれる有効成分を機器分析によって測定する。

雨卜イを用いた拡散性評価の結果より製剂を選抜し，温室 内モデル試験に供試する。この試験は幅 $25 \mathrm{~cm}$, 長さ $8 \mathrm{~m}$ の 水路に模擬水田を調製し，端から $50 \mathrm{~cm}$ の地点に薬剂を処理
し， $50 \mathrm{~cm}$ ごとに移植したイネへの薬害と除草効果を調査す

る。この評価系により製剤自体の拡散性能力を相対的に把握

し，拡散性がより良好な製郕に改良を重ねる。

\section{2. 小規模圃場試験}

実験室および温室規模の評価より選抜された製剤は戋場試 験に供試されるが，圃場規模で製剤自体の拡散性能力を評価 するために，小規模水田を用いたモデル試験を実施する.

以下に小規模圃場試験の実例を示す。除草剂有効成分とし てピリミノバックメチル $1.8 \%$, ブロモブチド $36.0 \%$, ベンス ルフロンメチル $2.0 \%$ ，ペントキサゾン $8.0 \%$ を含有する豆つ ぶ剂を調製し， $2 \mathrm{~m} \times 20 \mathrm{~m}$ の細長い水田の短辺側の端に，本 水田の面積に対応する薬量 $10 \mathrm{~g}$ を全量処理し, 処理 30 日後

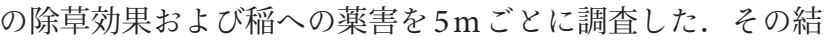
果, 処理地点から $20 \mathrm{~m}$ 地点の全域で, ノビエ, コナギ, 一 年生広葉に対して高い除草効果を示し，またイネに対する薬 害は問題なかった。以上の評価において，豆つぶ剤の自己拡 散力は非常に優れていることを確認した（Fig. 7).

\section{3. 実規模圃場試験}

最終的に実規模の戋場試験によって豆つぶ剤の拡散性を評 価する.

まず，農薬としての効果を確認するための試験として, $10 \mathrm{a}$ の水田を用い, 豆つぶ剂を畦畔から散布する実規模戋場 試験を実施する。

以下に実例を示す。除草剤有効成分としてピリミノバッ クメチル $1.8 \%$ ，ブロモブチド $36.0 \%$ ，ベンスルフロンメチル 2.0\%，ペントキサゾン $8.0 \%$ を含有する豆つぶ剂を調製し， $18 \mathrm{~m} \times 56 \mathrm{~m}$ の水田の畦畔から手まき散布を行い，処理 13 日 後と 38 日後の除草効果および稲への薬害を水田の四隅と中 央部分を対象に調查した。その結果，いずれの地点でも， ～ ビエ, コナギ，一年生広葉，イヌホタルイに対して高い除草 効果を示し，またイネに対する薬害は問題なかった，以上よ り, 豆つぶ剤の拡散性, 実用的な効果は問題ないことを確認 した.

また，豆つぶ剤の散布方法の妥当性評価として，種々の大 きさの水田に対し，第3節に記載した散布方法によって豆つ ぶ剂を施用後, 所定時間ごとに所定の場所から採水し，水の 中に含まれる有効成分を機器分析によって測定する.

以下に実例を示す．除草剂有効成分としてピリミスルファ ン $2.7 \%$ を含有する豆つぶ剤を調製し散布した。いずれも水 田の中には入らずに散布したが，散布条件については，水田 の規模や風向きなどを考慮し, 都度, 最も実用的と思われる 方法とした．各採水地点の水に含まれる成分濃度を分析し， 均一性の尺度として標準偏差を平均值で割った変動率を算出 した．数值は低い方がよいが, 評価期間内で $30 \%$ 以下であ れば実用上問題ないと考えている。いずれの散布方法におい 


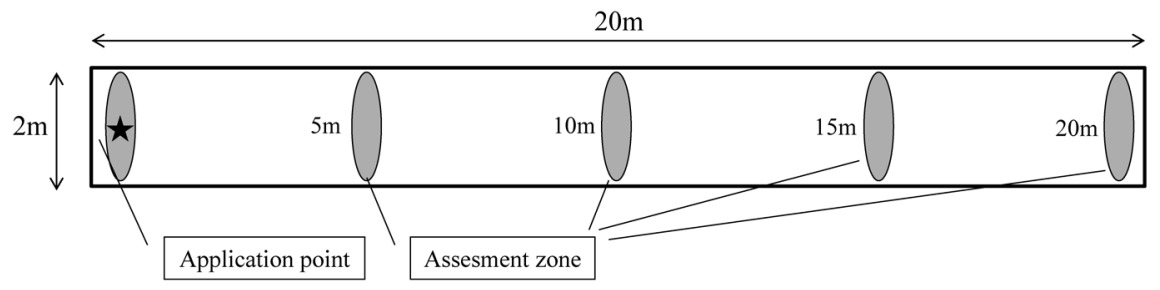

\begin{tabular}{|c|c|c|c|c|c|c|}
\hline L.S. at appication & A.P. & $5 \mathbf{m}$ & $10 \mathrm{~m}$ & $15 \mathrm{~m}$ & $20 \mathrm{~m}$ & Application date: 2002.5 .29 \\
\hline $\begin{array}{c}\text { Oryza sativa } \\
\text { 'Hitomebore' } \\
\text { (4.5L.S.) }\end{array}$ & 6 & 0 & 0 & 0 & 0 & $\begin{array}{l}\text { Final pudding date }: 2002.5 .11 \\
\text { Transplanted date: } 2002.5 .15\end{array}$ \\
\hline $\begin{array}{l}\text { Echinochloa spp. } \\
\text { (Pre 2.2 L.S.) }\end{array}$ & 100 & 100 & 100 & 94 & 100 & Assesment date:2002.6.28(30DAA) \\
\hline $\begin{array}{l}\text { Monochoria vaginalis } \\
\text { (Pre 1 L.S.) }\end{array}$ & 100 & 100 & 100 & 100 & 100 & $\begin{array}{l}* \text { L.S. }=\text { Leaf stage }\end{array}$ \\
\hline $\begin{array}{l}\text { Anuual Broadleaves } \\
\text { (Pre cotyledon) }\end{array}$ & 100 & 100 & 98 & 96 & 100 & $*$ A.P. $=$ Application point \\
\hline
\end{tabular}

Fig. 7. Field trial.

A

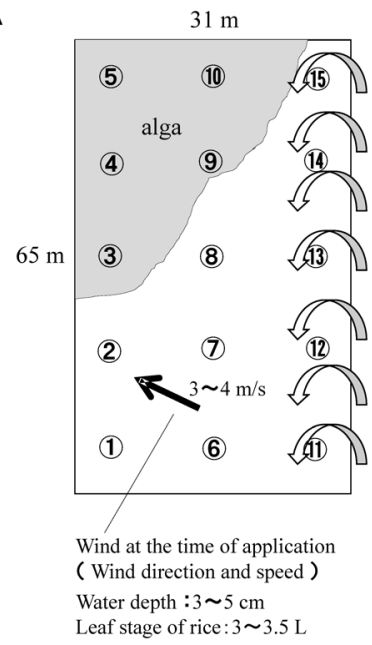

$B$

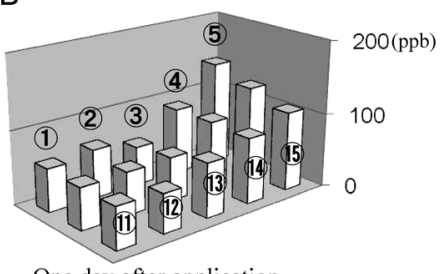

One day after application

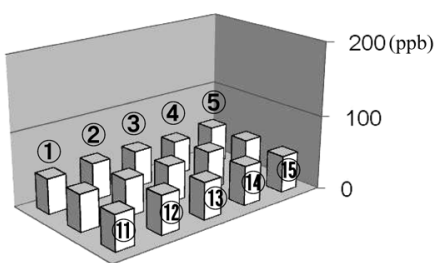

Three days after application

Fig. 8. Hand application. (A) Outline of the paddy field, and (B) spreadability of the ingredient.

Table 2. The application method and the coefficient of variation of each experiment

\begin{tabular}{llccc}
\hline \multicolumn{1}{c}{ Application method } & Paddy field scale & Application time & Coefficient of variation \\
\hline Hand application & One side of windward & $20 \mathrm{a}$ & $2 \mathrm{~min}$ & $3.7 \%$ \\
Package application & All sides & $20 \mathrm{a}$ & $5 \mathrm{~min}$ & $4.5 \%$ \\
Dipper application & All sides & 1 ha & $10 \mathrm{~min}$ & $15.1 \%$ \\
Engine duster applicatipn & All sides & $50 \mathrm{a}$ & $7 \mathrm{~min}$ & $7.8 \%$ \\
Unmanned helicopter application & Eight points & $85 \mathrm{a}$ & $3 \mathrm{~min}$ & $24.7 \%$ \\
Application to the water inlet & One point & $20 \mathrm{a}$ & Few sec & $6.0 \%$ \\
Jumbo formulation & 20 bags & $20 \mathrm{a}$ & $5 \mathrm{~min}$ & $7.5 \%$ \\
\hline
\end{tabular}

ても成分の均一性は良好であった（Table 2, Fig. 8 （手まき散 布のみ例示)). 以上より, 豆つぶ剂の各種散布方法の拡散性 は問題なく，散布方法として妥当であることを確認した。
おわりに

大きさが $3 \sim 8 \mathrm{~mm}$ 程度の豆つぶ状であり, 水面で崩壊分 散する水稲用の水面施用剤「豆つぶ剂」を開発した。この製 
剂は，水田に入ることなく，使用者が思った通りに畦畔から 散布することができる省力化製剤である，製剤自体の有効成 分の拡散性を水田のモデル試験を行って評価し, 非常に優れ た拡散性を示すことを確認した。また，実際の戋場を用いて 有効成分の拡散性を評価し, 農薬の効果としても実用上問題 ないことを確認した。農薬の散布を必要とする水田は必ず しも同じ状態ではないが，豆つぶ剤は多様な散布特性，およ びすぐれた拡散性により，大きさ，形状，風向風速，拡散性 の障害となる水面の浮遊物の状態など一様ではない水田に対 し, 合理的な農薬処理が可能な水面施用剤と考えられる.

豆つぶ剂は2000年に市場に登場したが, 当初は認知度が 高いジャンボ剂としての散布形態の方が使用面積も多かっ たものの, その後徐々にばら撒き型の散布形態も増加し, 近 年は当社の製剤比率においてジャンボ剤を上回るに至った。 また，日本で生まれた製剤が韓国にも渡り，2006年以降市 場で用いられるようになった，普及状況としては，2013年 末時点で, 日本国内の農薬登録数は 20 品目, 普及面積約 136,000 ha，海外は韓国で 5 品目，普及面積約 17,000 ha に 至った.

\section{謝 辞}

豆つぶ剂の登録，普及する上での種々の評価を実施して頂 いた公益財団法人日本植物調節剤研究協会, 一般社団法人日 本植物防疫協会, 一般社団法人農林水産航空協会, 全国農業 協同組合連合会の関係者の皆様に感謝致します。

\section{引用文 献}

1) 辻 孝三 : 日本の農薬開発, ソフトサイエンス社, p. 63, 2003.

2) 小池好智: 今月の農業, 化学工業日報社, 6月号, pp. 92-97, 2005.

3）藤田茂樹, 加藤 進: 農林水産技術研究ジャーナル 34, 21-24,
2011.

4) 藤田茂樹, 赤司宗貴, 櫻田直巳, 加藤 進: 第20回農薬製剤 施用法シンポジウム講演要旨集, p. 87, 2000.

5) 杉村俊雄, 赤司宗貴, 藤田茂樹, 大川哲生：日本農薬学会第 28 回大会講演要旨集, p. 115, 2003.

6）農薬概説, 日本植物防疫協会, p. 114, 2012.

7) http://www.jpo.go.jp/shiryou/s_sonota/hyoujun_gijutsu/nouyaku/ $0030 . h t m l(2015$ 年 2 月 3 日閲覧)

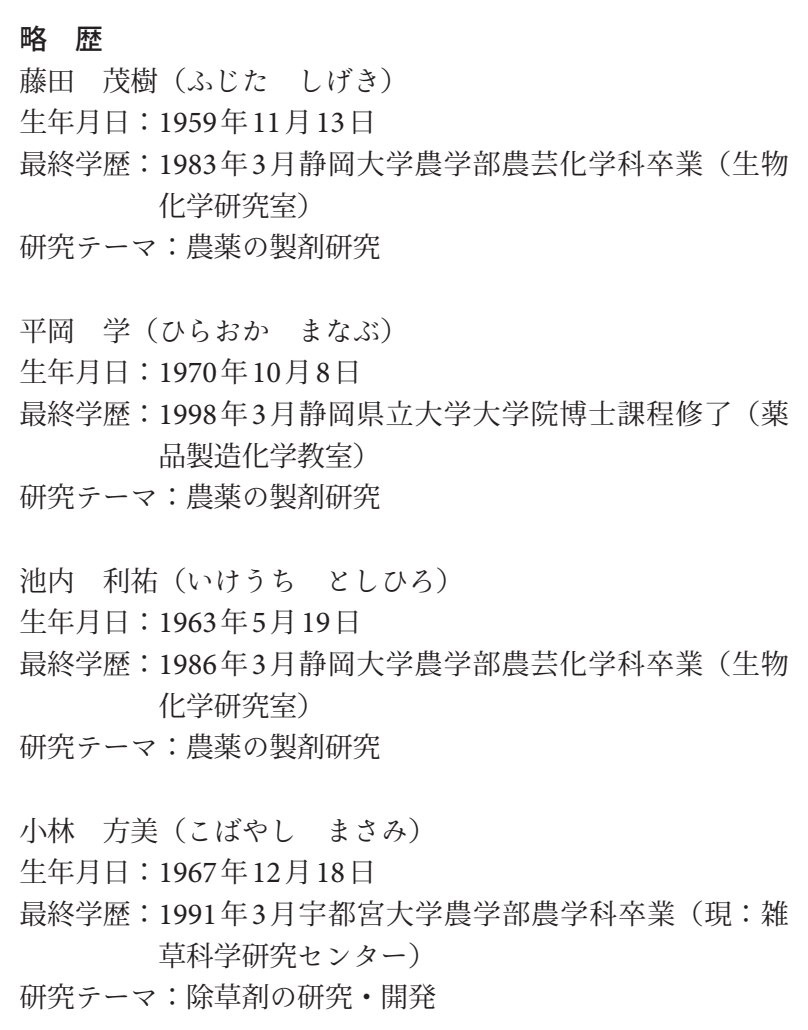

